\title{
WORK CONFLICT PADA SEORANG KARYAWAN YANG MENGALAMI BULLYING
}

\author{
Rooswita Santia Dewi, Muhammad Irfan Fauzan \\ Program Studi Psikologi, Fakultas Kedokteran, \\ Universitas Lambung Mangkurat Kalimantan Selatan \\ rooswita_santia_dewi@yahoo.co.id
}

\begin{abstract}
Abstrak
Salah satu faktor yang mempengaruhi pekerjaan seseorang ialah faktor kepemimpinan. Faktor kepemimpinan ialah kualitas dalam memberikan dorongan semangat, arahan, dan dukungan yang diberikan manajer dan team leader. Namun, apabila seorang pemimpin tidak memberikan semangat dan dorongan kepada anggotanya bahkan seperti melakukan tindakan bullying kepada anggotanya, tentu saja hal tersebut membawa dampak negatif kepada anggotanya. Karyawan yang mengalami bullying akan kurang mampu mengatasi tugas sehari-sehari dan bekerja sama di lingkungan kerjanya. Hal tersebut dapat menimbulkan konflik dalam sebuah organisasi. Penelitian ini bertujuan untuk melihat gambaran work conflict pada seorang karyawan yang mengalami bullying. Penelitian ini menggunakan metodologi kualitatif dengan teknik observasi dan wawancara. Temuan dari penelitian ini nenunjukkan bahwa subyek memiliki konflik individu dengan koorodinator di dalam organisasi yang dikarenakan perilaku bullying. Konflik yang terjadi antara subjek dan koordinator adalah konflik disfungsional. Hal tersebut membawa dampak negatif bagi subjek yaitu terhambatnya tujuan yang dikehendaki oleh organisasi.
\end{abstract}

Kata kunci : Work Conflict, Bullying, Karyawan

\begin{abstract}
One of the factors that affect someone's worked is leadership factor. Leadership factor is the quality in providing encouragement, direction, and support given by managers and team leaders. However, if a leader doesn't give encouragement to its members even as doing bullying to its members, of course it has a negative impact on its members. Employees who has bullying will be less able to handle daily tasks and work together in their work environment. It can create conflicts within an organization. This study aims to see the description of work conflict in an employee who has a bullying. This study uses qualitative methodology with observation and interview techniques. The findings from this study indicate that subjects has individual conflicts with coordinators within the organization due to bullying behavior. The conflict between the subject and the coordinator is a dysfunctional conflict. It carries a negative impact on the subject that's hampered by the goals that the organization wants.
\end{abstract}

Keyword: work conflict, Bullying, Employee. 


\section{PENDAHULUAN}

Pada situasi kerja, seseorang tidak akan lepas dengan yang namanya interaksi entah dengan teman seanggota kerja ataupun dengan atasan. Mahmudi (2005) menyebutkan bahwa faktor yang mempengaruhi pekerjaan seseorang ialah faktor kepemimpinan. Faktor kepemimpinan ialah kualitas dalam memberikan dorongan semangat, arahan, dan dukungan yang diberikan manajer dan team leader. Berdasarkan faktor yang mempengaruhi pekerjaan seseorang tersebut, seorang pemimpin haruslah memberikan semangat dan dorongan kepada anggotannya. Namun, apabila seorang pemimpin tersebut melakukan hal yang sebaliknya misalnya saja seperti melakukan perilaku bullying terhadap anggotanya tentu saja hal tersebut membawa efek negatif kepada anggotanya. Einarsen (2005) menyebutkan bahwa individu yang mengalami bullying juga menyebabkan karyawan kurang mampu mengatasi tugas sehari- hari dan bekerjasama dengan orang lain di lingkungan kerjanya dan dampak psikologisnya ialah menghasilkan reaksi emosional yang berat seperti ketakutan, kecemasan, ketidakberdayaan, depresi dan shock. Sullivan (2000) menyebutkan bahwa bullying adalah tindakan menyerang yang dilakukan secara sadar dan sengaja atau dimanipulasi oleh satu atau lebih banyak orang terhadap orang lain atau orang banyak. Berdasarkan survey yang dilakukan oleh Institute of Bullying in Workplace pada tahun 2006, terdapat beberapa bentuk bullying yang sering terjadi yaitu tuduhan (71\%), ancaman nonverbal (68\%), meremehkan pendapat orang lain (64\%), mengucilkan seseorang (64\%), menghindari memberikan pujian meskipun hasilkerja memuaskan (58\%), kritikan pedas dan menetapkan standar yang berbeda untuk suatu tugas (57\%), menyebarkan gosip mengenai seseorang (56\%) dan meminta orang lain untuk memperlakukan karyawan secara tidak adil (55\%) (Gholipour, Sanjari, Bod \& Kozekanan, 2011).

Einarsen (2005) menyebutkan bahwa bullying juga menyebabkan karyawan kurang mampu mengatasi tugas sehari- hari dan bekerja sama dengan orang lain di lingkungan kerjanya. Apabila seorang karyawan tidak mampu bekerja sama dengan orang lain misalnya seperti atasan. hal tersebut kemungkinan besar dapat menimbulkan sebuah konflik dalam sebuah organisasi.

Ivancevich (dalam Afrizal, dkk, 2014) menyebutkan salah satu bentuk konflik berdasarkan akibatnya terhadap perusahaan yaitu konflik disfungsional (dysfunctional conflict). Konflik disfungsional adalah setiap konfrontasi atau interaksi antarkelompok yang membahayakan organisasi atau menghambat organisasi dalam mencapai tujuan-tujuannya. Dalam hal ini, bullying termasuk dalam konflik disfungsional karena interaksi tersebut dapat membahayakan organisasi seperti karena adanya konflik tersebut karyawan tidak nyaman dalam menjalani pekerjaan.

Subjek dalam penelitian berinisial $\mathrm{YAH}$, ia berkuliah sambil bekerja untuk mengurangi beban orang tua. Subjek merupakan anak pertama dari 2 bersaudara. dia bekerja sudah 
selama kurang lebih 4 tahun dari tahun 2012 sampai dengan 2016 atau sekarang. Subjek mengalami pertentangan atau perselisihan baru sekitar 2 tahun. Saat dua tahun pertama subjek mengatakan tidak ada perselisihan apapun. Subjek mengatakan bahwa dia berkonflik dengan salah satu koordinator diperusahaannya. Penelitian ini bertujuan untuk mengeksplorasi dan memahami tentang work conflict yang terjadi pada karyawan yang mengalami bullying.

\section{Landasan Teori}

\section{Work Conflict}

a. Definisi Work Conflict

Winardi (dalam Afrizal, dkk, 2014) menyebutkan bahwa konflik merupakan suatu situasi, dimana terdapat berbagai tujuan atau berbagai emosi yang tidak sesuai satu sama lain, pada diri beberapa individu atau antara beberapa individu yang kemudian menyebabkan timbulnya pertentangan. Demikian juga menurut Robbin (2008) menyebutkan bahwa konflik adalah suatu proses yang dimulai ketika suatu pihak menganggap pihak lain secara negatif mempengaruhi atau akan mempengaruhi sesuatu/seseorang yang menjadi kepedulian pihak pertama.

\section{b. Ciri-Ciri Work Conflict}

Wijono (2010) menyebutkan menurut pandangan tradisional dan pandangan modern terhadap konflik, maka muncul pula beberapa ciri diantaranya:

i. Paling tidak ada dua pihak secara pribadi maupun kelompok yang terlibat dalam suatu interaksi yang saling bertentangan satu sama lain.

ii. Timbul pertentangan antara dua pihak secara pribadi maupun kelompok dalam mencapai tujuan, memainkan peran, ambigu, dan adanya nilai-nilai atau norma-norma yang bertentangan satu sama lain.

iii. Munculnya interaksi yang sering kali ditandai oleh gejala- gejala perilaku yang direncanakan untuk saling mengadakan, mengurangi, dan menekan terhadap pihak lain. Tujuannya adalah untuk memperoleh keuntungan fisik dan psikologis. Seperti kepercayaan diri, harga diri, relasi, gaji, mobil, dan jabatan.

iv. Munculnya tindakan yang saling berhadap-hadapan sebagai akibat dari adanya perselisihan dan pertentangan yang berlarut- larut.

v. Adanya ketidakseimbangan akibat dari usaha masing- masing pihak yang terkait misalnya kedudukan, status sosial, pangkat, golongan, kewibawaan, kekuasaan, harga diri, dan prestasi. 


\section{Bullying}

a. Definisi Bullying

Sullivan (2000) menyebutkan bahwa bullying adalah tindakan menyerang yang dilakukan secara sadar dan sengaja atau dimanipulasi oleh satu atau lebih banyak orang terhadap orang lain atau orang banyak. Bullying adalah sebuah penyalahgunaan kekuasaan oleh mereka yang melakukannya. Kadang direncanakan dan kadang dilakukan dengan opurtrunis. Papalia (2007) juga menyebutkan bahwa bullying adalah tindakan agresif yang dilakukan dengan tenang atau tanpa beban, disengaja dan berulang untuk menyerang target atau korban, yang secara khusus adalah seorang yang lemah, mudah diejek dan tidak dapat membela diri. Hal tersebut senada dengan menurut Olweus (dalam Amalia, 2000) yang menyebutkan bahwa bullying adalah perilaku yang menyakiti seseorang atau sekelompok orang baik dalam bentuk kekerasan fisik, verbal ataupun psikologis.

b. Bentuk Bullying

Sejiwa (dalam Simbolon, 2012) menyebutkan tiga bentuk praktek bullying yaitu:

i. Fisik

Bentuk bullying fisik adalah jenis bullying yang kasat mata. Contoh bullying fisik antara lain: menampar, menimpuk, menjegal, menginjak kaki, meludahi, memalak, melempar dengan barang, menghukum dengan cara push up.

ii. Verbal

Bentuk bullying verbal adalah jenis bullying yang juga bisa terdeteksi karena dapat tertangkap oleh indra pendengaran orang. Contoh bullying verbal antara lain: memaki, menjuluki, menghina, meneriaki, mempermalukan di hadapan umum, menuduh, menyoraki, menebar gosip, serta memfitnah.

iii. Mental atau Psikologis

Jenis bullying yang paling berbahaya adalah bullying mental atau psikologis, hal tersebut terjadi secara diam-diam dan di luar pemantauan orang. Contohnya adalah: memandang sinis, memandang penuh ancaman, mempermalukan di hadapan umum, mendiamkan, mengucilkan, mem-permalukan, meneror melalui pesan pendek telepon genggam atau email, memelototi, serta mencibir.

\section{METODE PENELITIAN KUALITATIF}

Metode penelitian dalam penelitian ini menggunakan metode penelitian kualitatif dengan 1 orang subjek berinisial $\mathrm{YAH}$ dan menggunakan significant other yaitu teman dan ibu subjek. Teknik pengumpulan data yang digunakan dalam penelitian ini ialah observasi dan wawancara. 
Teknik dan Tujuan Asesmen

\section{Observasi}

Teknik pengumpulan data pada penelitian ini menggunakan teknik observasi nonpartisipan. Observasi non-partisipan merupakan teknik dimana peneliti tidak terlibat dan hanya sebagai pengamat independen. Hal yang diobservasi dalam penelitian ini ialah observasi fisik dan gesture subjek saat wawancara. Observasi ini bertujuan untuk menambah data dari hasil wawancara.

\section{Wawancara}

Wawancara digunakan sebagai teknik pengumpulan data apabila peneliti ingin melakukan studi pendahuluan untuk menemukan permasalahan yang ingin di teliti, dan ingin mengetahui hal-hal dari responden secara mendalam. Teknik pengumpulan data ini mendasarkan diri pada laporan tentang diri sendiri atau self-report, atau setidak-tidaknya pada pengetahuan dan atau keyakinan pribadi.

Pada saat wawancara peneliti menggunakan teknik wawancara semi-terstruktur karena dilakukan lebih bebas dan bertujuan untuk menemukan permasalahan secara lebih terbuka. Wawancara dilakukan sebanyak empat kali yaitu kepada subjek yang mengalami bullying di perusahaannya sebanyak dua kali dan dua kali terhadap significant other yaitu kepada ibu subjek sendiri dan teman kerja subjek. Wawancara dengan significant other untuk mengetahui kesesuaian hasil wawancara terhadap subjek dan hasil wawancara terhadap orang terdekat subjek.

\section{HASIL \& PEMBAHASAN}

\section{Hasil Asesmen}

1. Identitas Subjek/Identitas Kasus

Subjek YAH lahir di Kelua,01Januari 1991 (26 Tahun), berjenis kelamin laki-laki dengan pekerjaan karyawan honorer.

\section{Riwayat Kasus}

Subjek kuliah sambil bekerja untuk mengurangi beban orang tua. Subjek merupakan anak pertama dari 2 bersaudara. dia bekerja sudah selama kurang lebih 4 tahun dari tahun 2012 sampai dengan 2016 atau sekarang. Subjek mengalami pertentangan atau perselisihan baru sekitar 2 tahun. Saat dua tahun pertama subjek mengatakan tidak ada perselisihan apapun. Subjek mengatakan bahwa dia berkonflik dengan salah satu koordinator diperusahaannya. Koordinator disini adalah orang yang diberi wewenang untuk mengkoordinir anak buah

\section{Hasil Observasi}

Observasi yang dilakukan yaitu observasi pada saat wawancara. Wawancara bertempat di rumah subjek yang pada saat itu suasana di rumah sedang ramai karena seluruh 
keluarga dari subjek berkumpul. Wawancara dengan duduk santai berhadapan, subjek mengenakan pakaian berwarna hijau dan celana pendek berwarna hijau tua. Subjek berambut gunduk semi. Kulit subjek berwarna sawo matang. Dalam menjawab pertanyaan peneliti, subjek begitu antusias dan ekspresif. Subjek menampilkan ekspresi muka yang jengkel saat menjelaskan hal-hal yang dialaminya saat melakukan pekerjaan di perusahaan tersebut. Subjek juga menggunakan beberapa gerakan tangan ketika berbicara dengan peneliti. Subjek juga sangat bersahabat saat menjawab pertanyaan yang diajukan oleh peneliti mengenai konflik-konflik yang terjadi diperusahaan tersebut.

\section{Hasil Wawancara}

Subjek yang menjadi narasumber adalah seorang karyawan yang mengalami bullying dan mempunyai konflik dengan salah satu orang diperusahaannya. Subjek menyebutkan bahwa dia bekerja sudah selama kurang lebih 4 tahun. Subjek mengalami pertentangan atau perselisihan baru sekitar 2 tahun. Saat dua tahun pertama subjek mengatakan tidak ada perselisihan apapun. Subjek mengatakan bahwa dia berkonflik dengan salah satu koordinator diperusahaannya. Koordinator disini adalah orang yang diberi wewenang untuk mengkoordinir anak buah.

Subjek mengatakan bahwa pernah terjadi percekcokan atau perdebatan antara subjek dengan koordinator. Perdebatan itu ialah masalah wilayah kerja yang tidak sesuai dengan job description dari perusahaan. Selain itu, subjek juga pernah berdebat dengan koordinator yang menyebutkan bahwa subjek tidak masuk bekerja, padahal subjek masuk bekerja. Perdebatan itu terjadi saat rapat dengan bagian manajemen perusahaan. Koordinator juga sering mengejek subjek seperti menjelek-jelekkan subjek kepada atasan dari perusahaan.Selain hal itu, subjek mengatakan bahwa biarpun subjek bekerja sungguh-sungguh tetap dibilang buruk oleh koordinator. Subjek menceritakan bahwa hal tersebut dilakukan koordinator kepada subjek lantaran koordinator menaruh dendam kepada subjek. Subjek juga mengalami perlakuan yang semena-mena seperti memindah wilayah kerja subjek tanpa sepengetahuan kepala divisi. Subjek juga menyebutkan bahwa penilaian checklist yang tidak sesuai dengan kenyataan, misalnya hari ini subjek bekerja dengan baik namun di-checklist buruk. Selain itu, penilain checklist ini mengada-ada karena untuk hari berikutnya sudah di-checklist koordinator tidak baik, padahal dilewati saja belum harinya tetapi sudah di-checklist buruk. Subjek juga mengalami pemfitnahan yang seharusnya subjek dapat pindah ke tempat kerja yang lebih bagus tetapi karena koordinator memfitnah subjek hal tersebut menjadi gagal. Saat masih bekerja difotokopi subjek mengatakan hal yang benar kepada koordinator, tetapi koordinator ini marah.

Subjek menanggapi perlakuan yang dilakukan koordinator kepada dirinya ialah dengan cara menghindari koordinator dan kurang hormat kepada koordinator. Subjek mengatakan bahwa koordinator ini seperti seorang bos yang bisanya hanya menyuruh-nyuruh 
seharusnya koordinator ini juga turun ke lapangan. Subjek juga menyebutkan bahwa dirinya pernah beradu argumen dengan koordinator karena koordinator menyebutkan bahwa subjek tidak turun bekerja di depan manajemen tapi subjek melawan hal tersebut karena tidak benar. Subjek juga menyebutkan bahwa koordinator ini apabila di depan subjek terlihat baik, tetapi apabila tidak di depan subjek koordinator atau sedang di depan atasan perusahaan koordinator menjelek-jelekkan subjek. Koordinator juga mengadu-ngadukan subjek ke manajer perusahaan karena subjek dibilang tidak turun bekerja padahal pada kenyataannya subjek tengah mengalami sakit dan surat sakit dari puskesmas pun ada, hal tersebut dikarenakan koordinator tidak suka dengan subjek.

Subjek juga menyayangkan perilaku manajemen yang tidak mau menyatukan karyawannya. Perasaan subjek saat bekerja tidak mood karena ada konflik ini, ingin izin untuk makan saja susah. Subjek juga memandang bahwa koordinator buruk dan tidak dihargai lagi oleh subjek. Subjek juga mengatakan bahwa merasa lelah dan malas bekerja karena diperlakukan semena-mena oleh koordinator. Subjek juga memiliki rasa ingin pindah atau berhenti bekerja dari perusahaan tersebut.

\section{Pembahasan}

Berdasarkan hasil yang didapatkan, subjek mengalami bullying oleh seorang koordinator yang memiliki kekuasaan yang lebih terhadap dirinya. Sullivan (2000) menyebutkan bahwa bullying adalah tindakan menyerang yang dilakukan secara sadar dan sengaja atau dimanipulasi oleh satu atau lebih banyak orang terhadap orang lain atau orang banyak. Bullying adalah sebuah penyalahgunaan kekuasaan oleh mereka yang melakukannya. Dalam hal ini, subjek mengalami bullyingseperti diperlakukan secara semenamena mengenai penempatan wilayah kerja, difitnah oleh koordinator yang memiliki kekuasaan, menuduh yang tidak benar, menjelek-jelekkan subjek dimata atasan, dan penekanan, serta ancaman-ancaman yang dilakukan koordinator terhadap subjek. Berdasarkan hal tersebut, Sejiwa (dalam Simbolon, 2012) menyebutkan tiga bentuk praktek bullying yaitu fisik, verbal, dan psikologis. Dalam hal ini, subjek mengalami tiga praktek bullying tersebut.

Dari hal tersebut, menghasilkan konflik antara subjek dengan koordinator tersebut dikarenakan memenuhi indikator-indikator dari konflik kerja itu sendiri yaitu perilaku perdebatan antara subjek dan koordinator, bersitegang dikarenakan masalah pribadi, tujuan yang berbeda mengenai masalah pekerjaan, perbedaan dalam berpendapat, perbedaan dalam menentukan penyebab permasalahan, perbedaan dalam menentukan solusi permasalahan antara subjek dan koordinator, perbedaan dalam menentukan cara penyelesaian konflik, adanya konflik emosional, adanya perselisihan mengenai masalah pribadi, dan subjek merasa lelah terhadap perlakuan yang diterimanya. Winardi (2004) 
menyebutkan bahwa konflik merupakan suatu situasi, dimana terdapat berbagai tujuan atau berbagai emosi yang tidak sesuai satu sama lain, pada diri beberapa individu atau antara beberapa individu yang kemudian menyebabkan timbulnya pertentangan. Berdasarkan hal tersebut, subjek dengan koordinator mengalami pertentangan dalam hal pekerjaan dikarenakan tujuan yang berbeda.

Berdasarkan penjelasan diatas, dampak konflik kerja pada diri subjek ialah dampak negatif yang menghasilkan kerja sama yang buruk antara koordinator dan subjek sendiri. Subjek YAH pun akhirnya memandang negatif pada koordinator dan subjek pun hanya bertegur sapa seadanya dengan koordinator. Hal tersebut sesuai dengan pernyataan Fauji (2013) yang menyebutkan bahwa menyebutkan bahwa pada tingkat hubungan antar-pribadi, konflik dapat merusak kerjasama kelompok. Ketidakpercayaan dapat tumbuh di antara orangorang yang semestinya mengkoordinasikan tugas-tugas atau kegiatan mereka. Selain itu, dampak dari perlakuan bullyingyang dilakukan koordinator kepada subjek ialah ketidaknyamanan dalam bekerja, kurangnya motivasi, dan adannya niat untuk berhenti bekerja dan pindah ke perusahaan lain. Hal tersebut sesuai dengan pernyataan Leymann (1996) yang menyebutkan bahwa bullying memiliki dampak kognitif terhadap karyawan yang mengalami bullying seperti masalah konsentrasi, ketidaknyaman dalam bekerja dan kurang inisiatif, serta bullying menyebabkan tingkat ketidakhadiran, niat untuk meninggalkan organisasi dan turnover yang lebih tinggi serta pensiun dini.

Dari hal itu dapat ditemukan bahwa konflik dalam perusahaan tersebut antara subjek dan koordinator, konflik tersebut menghambat perusahaan mencapai tujuan-tujuannya, seperti hilangnya motivasi bekerja subjek karena subjek menerima perlakuan dari koordinator yang tidak semestinya. Hal tersebut mengakibatkan mood dari subjek hilang untuk bekerja. Dalam hal ini, Ivancevich (dalam Afrizal, dkk, 2014) menyebutkan beberapa bentuk konflik berdasarkan akibatnya terhadap perusahaan, yaitu konflik fungsional dan konflik disfungsional. Konflik disfungsional adalah setiap konfrontasi atau interaksi antarkelompok yang membahayakan organisasi atau menghambat organisasi dalam mencapai tujuantujuannya. Berdasarkan penjelasan diatas dapat disimpulkan bahwa bentuk konflik antara subjek dan koordinator adalah konflik disfungsional karena dapat menghambat tujuan-tujuan yang ingin dicapai oleh organisasi.

Papalia (2007) menyebutkan bahwa bullying adalah tindakan agresif yang dilakukan dengan tenang atau tanpa beban, disengaja dan berulang untuk menyerang target atau korban, yang secara khusus adalah seorang yang lemah, mudah diejek dan tidak dapat membela diri. Kekhasan dalam penelitian ini dimana subjek berani membela diri dan menentang koordinator atas bullying yang dialaminya. Keberanian subjek untuk melawan perlakuan koordinator yang menimbulkan adanya work conflict antara subjek dan koordinator tersebut. 


\section{SIMPULAN}

\section{Kesimpulan}

Berdasarkan penelitian yang sudah dilakukan peneliti dapat disimpulkan bahwa subjek YAH:

1. Subjek mengalami perilaku bullying oleh koordinator dengan bentuk perlakuan semenamena yang diterima subjek saat bekerja, menjelek-jelekkan nama baik subjek, pemfitnahan yang diterima subjek, dan subjek mendapatkan tekanan serta ancaman saat bekerja.

2. Perlakuan bullying yang dilakukan koordinator kepada subjek menghasilkan konflik kerja antara subjek dan koordinator.

3. Konflik kerja tersebut ditandai dengan perilaku perdebatan antara subjek dan koordiantor, bersitegang dikarenakan masalah pribadi, tujuan yang berbeda mengenai masalah pekerjaan, perbedaan dalam berpendapat, perbedaan dalam menentukan penyebab permasalahan, perbedaan dalam menentukan solusi permasalahan antara subjek dan koordinator, perbedaan dalam menentukan cara penyelesaian konflik, adanya konflik emosional, adanya perselisihan mengenai masalah pribadi, dan subjek merasa lelah terhadap perlakuan yang diterimanya.

4. Bentuk konflik antara subjek dan koordinator adalah konflik disfungsional karena dapat menghambat tujuan-tujuan yang ingin dicapai oleh organisasi.

\section{Saran}

Berdasarkan hasil penelitian yang telah dilakukan, maka dapat diberikan saran sebagai berikut:

1. Saran untuk subjek

Diharapkan subjek YAH dapat menjadikan konflik yang terjadi dalam perusahaannya sebagai motivasi untuk subjek berkembang dalam bekerja. Selain itu, agar mengurangi beban yang diterimanya mengenai perlakuan koordinator, subjek dapat mengadukan hal tersebut dengan bagian manajemen disertai dengan alasan atau bukti yang sangat mendukung.

2. Saran untuk Organisasi atau Perusahaan

Diharapkan organisasi atau perusahaan dapat menampung aspirasi-aspirasi dan mendengarkan cerita-cerita dari karyawannya seperti memfungsikan atau mengadakan secara optimal konselor-konselor yang dapat membantuk permasalahan karyawan. 


\section{DAFTAR PUSTAKA}

Afrizal, P. R., Musadieq, M. A., Ruhama, I. (2014). Pengaruh Konflik Kerja dan Stres Kerja Terhadap Kepuasan Kerja (Studi pada Karyawan PT. TASPEN (PERSERO) Cabang Malang). J urnal Administrasi -Bisnis (J AB), Vol. 8. No. 1, pp. 1-10.

Amalia, D. (2010). Hubungan Persepsi Tentang Bullying dengan Intensi Melakukan Bullying Siswa SMA Negeri 82 Jakarta. Skripsi.

Einarsen, S. (2005). The Nature, Causes and Consequences of Bullying at Work: The Norwegian Experience. Perspectives interdisciplinaires sur le travail et la santé, Vol. 7. No. 3.

Fauji, H. (2013). Pengaruh Stres Kerja dan Konflik Kerja terhadap Semangat Kerja Karyawan di PT. Karya Mandiri Enviroment. Skripsi.

Leymann, H. (1996). The Content and Development of Mobbing at Work. European J ournal of Wok and Organizational Psychology, Vol. 5. No. 2, pp. 165-184.

Mahmudi. (2005). Manajemen Kinerja Sektor Publik. Yogyakarta: UPP AMP YKPN.

Papalia, D. E., Olds, S. W., \& Feeldman, R. D (2007). Human Development. (9th ed.). New York: McGraw-Hill.

Robbin, S. P. \& Timothy A. Judge. (2008). Perilaku Organisasi, alih basasa oleh Hadyana Pujaatmaka Salembat Empat, Jakarta.

Simbolon, M. (2012). Perilaku Bullying pada Mahasiswa Berasrama. J urnal P sikologi, Vol. 39. No. 2, pp. 233-243.

Sullivan, K. (2000). The Anti-bullying Handbook. New Zealand: Oxford University Press.

Wijono, S. 2010. Psikologi Industri dan Organisasi. Jakarta: Kencana Prenada Media Group.

Winardi. (1994). Manajemen Konflik (Konflik Perubahan dan Pengembangan). Bandung: Mandar Maju.

Winardi. (2004). Manajemen Perilaku Organisasi. Jakarta: Pustaka Binaman Presindo. 